\title{
MEASUREMENT OF RADON GAS CONCENTRATION IN FERTILIZER SAMPLES USING IRRADIATED CR-39 NUCLEAR TRACK DETECTOR
}

Nouh, S.A. ${ }^{(1)}$; El-Desoky, T. ${ }^{(2)}$; Diab, H. M. ${ }^{(3)}$; Mokhtar, . $^{(4)}$ and Hassan, M. $^{(5)}$

1) Faculty of Science, Ain Shams University.2) Faculty of Girls for Arts, Science and Education, Ain Shams University. 3) Nuclear and Radiological Regulatory Authority. 4) Egypt Air Cargo, Cairo, Egypt.

\begin{abstract}
In the present work, we have measured the radon gas concentration; effective dose and exhalation rate for some fertilizers samples, raw materials, triple super phosphate and single super phosphate by using alpha-emitters registrations that are emitted from radon gas in CR-39 nuclear track detector after irradiated with gamma rays. The results indicated that the highest average radon gas concentration in fertilizer samples was found in raw material, triple super phosphate (T.S.P) samples $\left(269.620 \mathrm{~Bq} / \mathrm{m}^{3}\right.$ and 186.8 $\mathrm{Bq} / \mathrm{m}^{3}$, respectively) while the lowest average radon gas concentration was found in single super phosphate ( S.S.P.) for powder and granules samples, $79.6 \mathrm{~Bq} / \mathrm{m}^{3}$ and $52.90 \mathrm{~Bq} / \mathrm{m}^{3}$, respectively. These results show that the radon concentration; effective dose and exhalation rate in all fertilizers samples and waste product are below the allowed limit according to the International Commission of Radiation Protection agency.

Key words: Gamma irradiation, Alpha particle, CR-39.
\end{abstract}

\section{INTRODUCTION}

Radiation processing is a useful technology to induce suitable modifications of materials. The interest in radiation treatment of polymers has increased, prompted by the radiations induced modifications of the properties of various polymeric materials. The physical and chemical modifications 
induced in polymers under radiation are triggered by the energy loss by the radiation within the target. Solid state nuclear track detectors (SSNTD) are used widely in several technical applications for the detection of charged particles from protons to heavy ions, as well as the simple registration of the particle flux density or the fluencies in the environmental dosimetry (Hermsdorf et al., 2007). On the other hand, phosphate ore is the raw material used in production of some fertilizers. It contains various amounts of natural radioactive elements. During the phosphate ore processing, owing to chemical properties of Radium, practically all ${ }^{226} \mathrm{Ra}$ gets incorporated into phosphorgypsum and remains in disequilibrium status when compared to radioactivity levels contained in the raw material. Most of the phosphogypsum is considered waste and is stockpiled or discharged into the aquatic environment (UNSCAR 2000). Potential issues of concern resulting from phospho-gypsum disposal are its environmental impacts; possible increases in radio- nuclides in soils or in groundwater and consequential ingestion by humans through exposure routes such as drinking water and food chain (Laich, 1995). Once, deposited in bone tissue; ${ }^{226} \mathrm{Ra}$ has a high potential for causing biological damage through continuous irradiation of human skeleton over many years and may induce bone sarcoma (Marovic et.al., 1995). The natural radionuclides of concern are mainly Potassium, Uranium, Thorium, and the radio-nuclides that are created as their radioactive decay chains. Emanation of Radon ${ }^{222} \mathrm{Rn}$ and ${ }^{220} \mathrm{Rn}$ of half life time's $3.8 \mathrm{~d}$ and $65 \mathrm{~s}$ into air occurs as a product of uranium ${ }^{238} \mathrm{U}$ and thorium ${ }^{232} \mathrm{Th}$ decay chains, respectively. The short lived decay products of radon are responsible for most 
of the hazards by inhalation. The hazard of Radon comes from its radioactive progeny, which use their physical properties to spread or attach like aerosols, trapped in the lung and depositing their alpha-particle energies in the tissue, producing higher ionization density than beta particles or gamma-rays. Lung \& skin cancer, and kidney diseases are the health effects attributed to inhalation of radon-decay products (Kumar, 1986). The sources of radon gas are the building materials and its components, ground water, and soil (Ahmad, et.al, 1998). The radiological impact from the above nuclides is due to radiation exposure of the body by the gamma rays and irradiation of the lung tissues from inhalation of Radon and its progeny ( Papastefanou, et.al; 1983). From the natural risk point of view, it is necessary to know the dose limits of public exposures and to measure the natural environmental radiation level provided by ground, air, water, foods, building interiors etc., for the estimation of the exposures to natural radiation sources. (IAEA; 1989). The aim of the present study is not only to enhance the dosimetric properties of CR-39 but also to use it in the determination of radon concentration level in some fertilizer samples and some of its products besides the annual effective dose (AED).

\section{MATERIAL AND METHODOLOGY}

\section{Material:}

The present investigation is based on the study of different kinds of fertilizer samples which was available in the local market, some of them are products from factory A in Abo Zabal area and another factory B present in Kafer Al Zyat area. The samples under investigation were in four forms, raw 
material, triple super phosphate (T.S.P), single super phosphate (S.S.P), beside waste products. The determination of the concentrations of alpha particles emitted from radon gas in fertilizer samples were performed by using enhanced CR-39 nuclear track detector of thickness $(500 \mu \mathrm{m})$ which was irradiated with $20 \mathrm{~Gy}$.

\section{Methodology:}

\section{Pre gamma irradiation:}

Samples from CR-39 sheets were irradiated using $\mathrm{CO}^{60}$ gamma source in the dose range 10-100 Gy, then exposed to alpha particles from $\mathrm{Am}^{241}$ source. Figure (1) shows the variation of track density against the pre gamma dose. From the figure, it is obvious that the track density increases up to a maximum value around the $20 \mathrm{~Gy}$ irradiated sample, then almost decreases with increasing the gamma dose up to $100 \mathrm{~Gy}$.

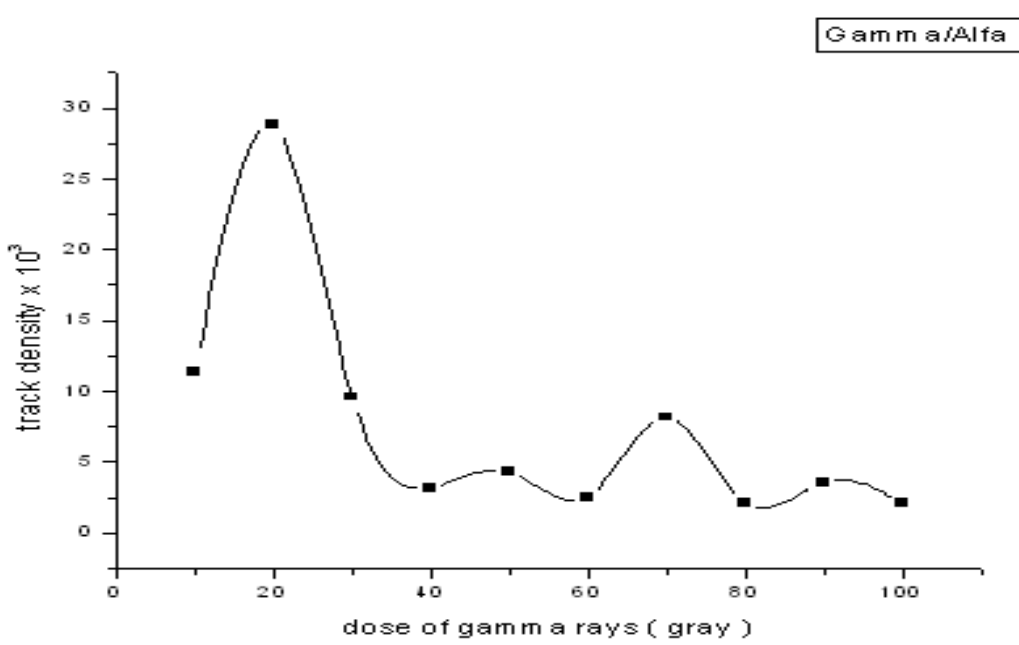

Figure (1) Variation of track density with the pre gamma dose 


\section{Post gamma irradiation:}

Another group of samples were irradiated with alpha particles, and then exposed to gamma irradiation with the same doses.

Figure (2) shows the variation of track density with the post gamma dose. From the figure, it is clear that the track density increases up to a maximum value around the $40 \mathrm{~Gy}$ irradiated sample then decreases around the $50 \mathrm{~Gy}$ irradiated sample due to track overlapping. Above 50 and up to $100 \mathrm{~Gy}$ it increased again.

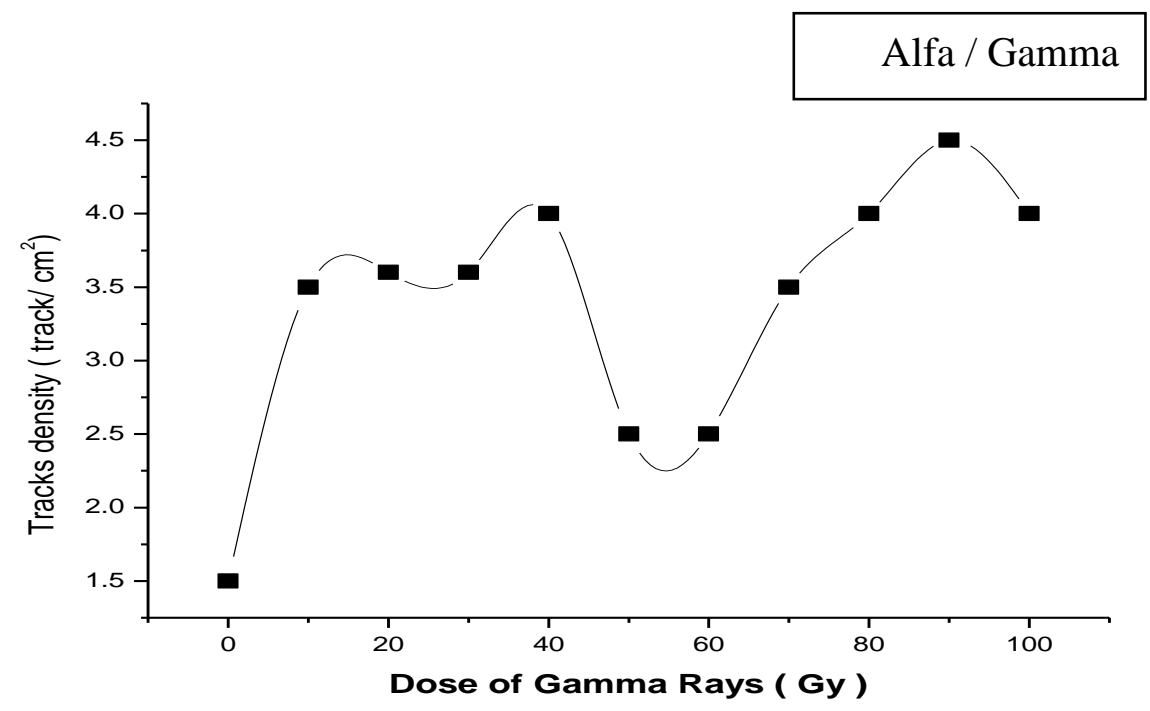

Figure (2) Variation of track density with the post gamma dose

The radon gas concentration in fertilizer samples was obtained by using the sealed-cup technique as shown in Figure 3. The irradiated CR-39 detectors were etched in $6.25 \mathrm{~N} \mathrm{NaOH}$ at temperature of $70{ }^{0} \mathrm{C}$ for $6 \mathrm{~h}$. Then the tracks density were recorded using an optical microscope with 
magnification 400x.The tracks density $\rho$ in the samples were calculated according to the following relation (Amalds et.al., 1989].

$$
\mathbf{C}=\frac{\rho}{K t}
$$

Where $\rho, t$ and $K$ are the track density, the exposure time in hours and calibration factor $K=0.16 \alpha$-tracks $\mathrm{cm}^{-2} \cdot \mathrm{d}^{-1}$ per Bq. $\mathrm{m}^{-3}$ of radon. The track density can be calculated from the following relation The track Density $(\rho)\left(\right.$ track cm$\left.{ }^{-2}\right)=\frac{\text { Average of total tracks }}{\text { Area of field of view }}$

$$
\rho=\frac{N-N_{B}}{S M}
$$

where $N, N_{B}, M$ and $S$ are the number of tracks, background, number of fields and area of view, respectively. The radon gas concentration in the fertilizer samples were obtained by the comparison between track densities registered on the detectors before and after irritation. The sample was placed in sealed cup at bottom of cylindrical sealed can of $6 \mathrm{~cm}$ diameter and $14 \mathrm{~cm}$ height. The mouth of cylindrical can was sealed with cover and fitted with enhanced CR-39 plastic track detector $(1 \mathrm{~cm} \times 1 \mathrm{~cm})$ at top inner surface. The detector records the tracks of $\alpha$ - particles emitted by radon gas produced through the $\alpha$ - decay of radium contents of the samples. The detectors were exposed for a period of about 90 days. After exposure, the detectors were retrieved and etched for six hours in $6.25 \mathrm{~N} \mathrm{Na} \mathrm{OH}$ solution maintained at temperature of $70{ }^{\circ} \mathrm{C}$ in a constant water bath to reveal the tracks. 


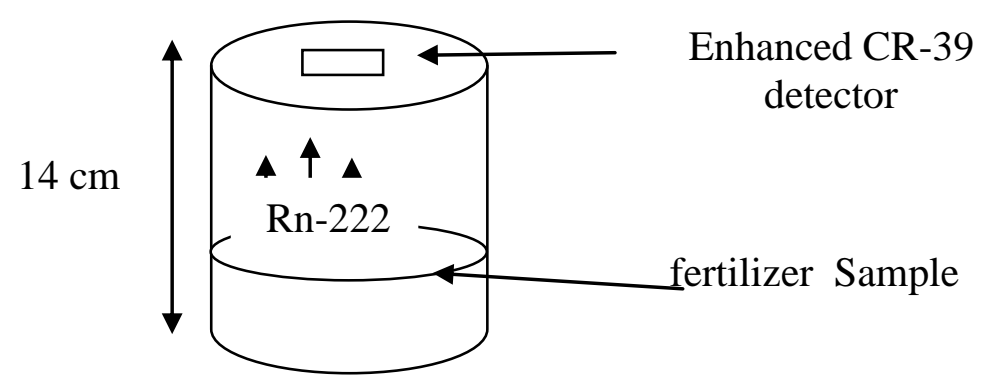

Figure (3): A schematic diagram of the sealed -cup technique in fertilizer sample.

\section{Calculation of radon exhalation rate in fertilizer samples:}

The radon exhalation rate of any sample is defined as the flux of radon released from the surface of material. The exhalation rate $\left(E_{A}\right)$ in unit $B q m^{-2}$ $\mathrm{h}^{-1}$ can be calculated by ( Mahur, 2010)

$$
\begin{gathered}
\text { C V } \lambda \\
\left.E_{A}=-1 T+\lambda^{-1}\left(e^{-\lambda T}-1\right)\right]
\end{gathered}
$$

Where

$\mathrm{C}$ : is the integrated Radon concentration $\left(\mathrm{Bq} \cdot \mathrm{m}^{-3}\right)$.

$\mathrm{V}$ : is the effective volume of air in $\operatorname{cup}\left(\mathrm{m}^{3}\right)=0.0001997 \mathrm{~m}^{3}$

$\lambda$ :is the decay constant for ${ }^{222} \mathrm{Rn}\left(\mathrm{h}^{-1}\right)=0.1812$ day $^{-1}=0.00755 \mathrm{~h}^{-1}$

A: is the surface area of the sample $\left(\mathrm{m}^{2}\right)=3^{2} \times 3.14=28.26 \mathrm{~cm}^{2}=0.002826 \mathrm{~m}^{2}$

$\mathrm{T}:$ is the exposure time $=90$ day and $\mathrm{T}_{\text {eff. }}=84.45$ day $\left[\mathrm{T}+\lambda^{-1}\left(\mathrm{e}^{-\lambda \mathrm{T}}-1\right)\right]$

The annual effective dose $\left(\mathbf{H}_{\mathbf{E}}\right)$ is calculated using the following expression: (UNSCEAR, 2000)

$\mathrm{H}_{\mathrm{E}}\left(\mathrm{mSv} \mathrm{y}^{-1}\right)=\mathrm{C}_{\mathrm{Rn}} \times \mathrm{F} \times \mathrm{H} \times \mathrm{T} \times \mathrm{D}$ 
Where $\mathrm{F}$ is the equilibrium factor and it is equal to $0.4, \mathrm{H}$ is the occupancy factor which is equal to $0.8, \mathrm{~T}$ is the time in hours in a year $(8760$ $\mathrm{h}^{-1}$ ) and (D) is the dose conversion factor which is equal to $\left[9 \times 10^{-6}(\mathrm{~m}\right.$ $\left.\mathrm{Sv}) /\left(\mathrm{Bq} \cdot \mathrm{h} \cdot \mathrm{m}^{-3}\right)\right]$.

The lung cancer cases per year per million person (CPPP), was obtained using the relation $(\mathrm{CPPP})=\mathrm{H}_{\mathrm{E}} \times\left(18 \times 10^{-6} \mathrm{mSv}^{-1} \cdot \mathrm{y}\right)$

\section{RESULTS AND DISCUSSION}

The interpretation of these results can be that the gamma irradiation of CR-39 in the dose range up to 20Gy causes chain scission. The free radicals produced from scission are chemically active and can cause crosslinking on gamma irradiation at the dose range 20-100 Gy. It is well known that track registration properties of the latent tracks are affected by exposing such detectors to gamma radiation (Jain, et.al, 2014 and Emad, et.al, 2015). The present findings clearly indicate the increasing relation between the bulk etching rate and gamma dose agree with that previously reported by (|AbuJarad et al., 1997). The behavior of the removal thickness percentage with etching time is in agreement with that previously reported by (Malik et al., 2002) The increasing relation between the removal thickness percentage and etchant concentration may be related to the attack by hydroxide ion results in the hydrolysis of the carbonate ester bonds and the release of polyallyalcohol from the polymer network (Brydson, 1975). The damage that appears in Figure( 2) according to the degradation caused by the gamma rays interaction with the samples in addition to the etchant solution attack with the polymeric material of samples (Kuleznev and Shershnev, 1990). When ionizing particle 
passes through a plate of plastic, it produces a latent track as a result of damage caused by the energy deposition of the particle. This track can be made optically visible by means of chemical etching. Table (1), presents the Radon gas concentration, effective dose and exhalation rates for different kinds of fertilizer samples. The table illustrates that the highest average radon gas concentration in fertilizer samples was found in raw material equal to $269.620 \mathrm{~Bq} / \mathrm{m}^{3}$ then triple super phosphate (T.S.P), which was (186.8 $\mathrm{Bq} / \mathrm{m}^{3}$ ), while the lowest average radon gas concentration in fertilizer samples was found in single super phosphate (S.S.P), which was $\left(79.6 \mathrm{~Bq} / \mathrm{m}^{3}\right.$ ). Also the effective dose and radon exhalation rate for raw material and T.S.P. are higher than that for S.S.P. and waste product The present results show that all values in all fertilizer samples are below the allowed limit from the International Commission of Radiation Protection (ICRP) agency.

Table 1: The Radon gas concentration, Effective dose and Exhalation rates for different kinds of fertilizer samples

\begin{tabular}{|c|c|c|c|c|}
\hline sample & $\begin{array}{c}\text { Track } \\
\text { density } / \mathbf{C m}^{2} \\
\end{array}$ & $\begin{array}{c}\text { Rn222 } \\
\text { Conc.Bqm }^{-3} \\
\end{array}$ & $\begin{array}{c}\text { Effective dose } \\
\mathrm{mSv} / \mathrm{y}\end{array}$ & $\begin{array}{c}\text { Exhalation rates } \\
\qquad \mathbf{B q} \mathbf{~ m}^{-2} \mathbf{h}^{-1} \\
\end{array}$ \\
\hline T.S.P & & $\begin{aligned} \mathrm{k} . \mathrm{t} & =0.168 * 90 \\
& =15.12\end{aligned}$ & $\begin{array}{c}\mathrm{D}=\mathrm{CR} * 0.4 * .8 * 76 \\
0 * 9 * 10^{-6=25228.8}\end{array}$ & \\
\hline S1 & 2940 & 194.44 & 4.86 & 0.103 \\
\hline $\mathrm{S} 2$ & 2760 & 182 & 4.55 & 0.09 \\
\hline S3 & 2820 & 186.5 & 4.66 & 0.099 \\
\hline Average & & 186.8 & 4.712 & 0.097 \\
\hline \multicolumn{5}{|l|}{ S.S.P .powder } \\
\hline S1 & 1140 & 75 & 1.89 & 0.040 \\
\hline S2 & 1260 & 83.3 & 2.08 & 0.044 \\
\hline S3 & 1220 & 80.5 & 2.01 & 0.042 \\
\hline Average & & 79.6 & 2.00 & 0.042 \\
\hline S.S.P. Granules & & & & \\
\hline
\end{tabular}


J. Environ. Sci.

Institute of Environmental Studies and Research - Ain Shams University

Table 1 ( contin.)

\begin{tabular}{|c|c|c|c|c|}
\hline sample & $\begin{array}{c}\text { Track } \\
\text { density/Cm }\end{array}$ & $\begin{array}{c}\text { Rn222 } \\
\text { Conc.Bqm }^{-3} \\
\end{array}$ & $\begin{array}{c}\text { Effective } \\
\text { dose } \mathrm{mSv} / \mathrm{y}\end{array}$ & $\begin{array}{l}\text { Exhalation rates } \\
\qquad \mathbf{B q ~}^{-2} \mathbf{h}^{-1 / \prime} \\
\end{array}$ \\
\hline S1 & 760 & 62.16 & 1.568 & 0.026 \\
\hline S2 & 720 & 47.61 & 1.19 & 0.025 \\
\hline S3 & 740 & 48.94 & 740 & 0.026 \\
\hline Average & & 52.90 & 1.33 & 0.025 \\
\hline \multicolumn{5}{|c|}{ Raw material } \\
\hline $\mathrm{S} 1$ & 4000 & 264.5 & 6.61 & 0.144 \\
\hline $\mathrm{S} 2$ & 4110 & 271.82 & 6.79 & 0.144 \\
\hline S3 & 4120 & 272.8 & 6.82 & 0.144 \\
\hline Average & 4076.66 & 269.620 & 6.74 & 0.144 \\
\hline \multicolumn{5}{|c|}{ Waste product } \\
\hline $\mathrm{S} 1$ & 1380 & 92 & 2.32 & 0.048 \\
\hline S2 & 1320 & 87.30 & 2.18 & 0.046 \\
\hline S3 & 1300 & 85.97 & 2.14 & 0.045 \\
\hline Average & 1333.33 & 88.12 & 2.22 & 0.046 \\
\hline \multicolumn{5}{|c|}{ phosphogypsum } \\
\hline $\mathrm{S} 1$ & 1060 & 70.1 & 1.75 & 0.037 \\
\hline S2 & 1000 & 66.3 & 1.65 & 0.035 \\
\hline S3 & 980 & 64.4 & 1.60 & 0.034 \\
\hline Average & 1013.33 & 67.01 & 1.69 & 0.035 \\
\hline
\end{tabular}

\section{CONCLUSION}

The radon concentration, effective dose and exhalation rate for different fertilizer samples products from Abo-Zabal, and Kafer Alzyat factories were found that the maximum average values of raw material for radon concentration, effective dose, exhalation rate were $269.62 \mathrm{~Bq} / \mathrm{m}^{3}, 6.74$ $\mathrm{mSv} / \mathrm{y}, 1.44 \mathrm{~Bq} \mathrm{~m}^{-2} \mathrm{~h}^{-1}$ respectively and T.S.P was found that $186.8 \mathrm{~Bq} / \mathrm{m} 3$, $4.712 \mathrm{mSv} / \mathrm{y}, 0.079 \mathrm{~Bq} \mathrm{~m}^{-2} \mathrm{~h}^{-1}$ respectively and lower average values for single super phosphate (S.S.P.) powder were $79.6 \mathrm{~Bq} / \mathrm{m}^{3}, 2.0 \mathrm{mSv} / \mathrm{y}, 0.042$ $\mathrm{Bq} \mathrm{m}^{-2} \mathrm{~h}^{-1}$ respectively, S.S.P granules $52.90 \mathrm{~Bq} / \mathrm{m}^{3}, 1.33 \mathrm{mSv} / \mathrm{y}, 0.025 \mathrm{~Bq}$ 30 
$\mathrm{m}^{-2} \mathrm{~h}^{-1}$ respectively and wast product average values were $88.12 \mathrm{~Bq} / \mathrm{m}^{3}, 2.22$ $\mathrm{mSv} / \mathrm{y}, 0.046 \mathrm{~Bq} \mathrm{~m}^{-2} \mathrm{~h}^{-1}$, phosphogypsium average values were $67.01 \mathrm{~Bq} / \mathrm{m}^{3}$, $1.69 \mathrm{mSv} / \mathrm{y}, 0.035 \mathrm{~Bq} \mathrm{~m}^{-2} \mathrm{~h}^{-1}$ respectively. All values are lower than the recommendation of International Commission on Radiological Protection range, (ICRP,1993)

\section{REFERENCES}

Abu Murad K. M. and Al-Omari R. A. (2008): "Indoor radon levels in Irbid and health risks from internal doses" Radiation Measurements, 43, S389-S391.

Abu-Jarad F. , Hal A.M. , Farhat M., Islam M (1997): Effect of high gamma dose on the PADC properties. Radiation Measurements 28: 111114.

Ahmad N., Matiullah A. H., Khatibeeh A. J. ( 1998 ): Comparative studies of indoor radon concentration levels in Jordan using CR-39 based bag and cup dosimeters, Health Phys 75, 60-62,

Amalds, Custball N.H. and Nielsen G.A. (1989) "Cs137 in Montarq Soils ", Health Physics, 57, 955-958

Durrani S.A. and Bull R.K., (1987): Solid State Nuclear Track Detection: Principles, Methods and Applications" Pergammon Press,U.K

Emad N., Esissa M.F , Emad Badawi , El-Fayoumi M. A. K. (2015) " Study the effect of irradiation positions on the microstructure of CR-39" . The First International Conference on Radiation Physics and Its Applications ICRPA-1, At Alexandria, Egypt.

Hermsdorf D., Hunger M., Stark S., Weickert F. (2007): Measurement of bulk etch rates for poly-allyl-diglycol carbonate (PADC) and cellulose nitrate in a broad range of concentration and temperature of $\mathrm{NaOH}$ etching solution. Radiation Measurements 42, 1-7.

ICRP, (1993): "Protection Against Rn-222 at Home and at Work" International Commission on Radiological Protection Publication 65. Ann. ICRP 23 (2). Pergamon Press; Oxford, 
International Atomic Energy Agency (1989): Measurements of radio nuclides in food and the environment. Vienna, IAEA; Technical Reports Series 295,

Jain R. K., Ashok Kumar, Chakraborty R.N. and Nayak B.K. (2014):" Irradiation effect of $60 \mathrm{Co}$ gamma rays on bulk etch rate, track etch rate and activation energy of CR-39 Solid State Nuclear Track Detector Proceedings of the DAE Symp. on Nucl. Phys. 59

Kuleznev VN, Shershnev VA (1990): The chemistry and physics of polymers. Union Soviet Socialist Republics.

Kumar S., S. Chander, G. S. Yaday, A. P. Shama, (1986): Some environmental effect studies on the response of (CR-39) plastic track detector, Nuclear Tracks 12, 129-132,

Laich T.P. (1991): A radiological evaluation of phosphogypsum, Health Phys., 60, 691-693

Mahur, A.K., Kumar, R., Mishra, M., Ali, S.A., Sonkawade, R.G., Singh, B.P., Bhardwaj, V. \& Prasad, R. (2010): Study of radon exhalation rate and natural radioactivity in soil samples collected from East Singhbhum Shear Zone in Jaduguda U-Mines Area, Jharkhand, India and its radiological implications Ind. J. Pure and Appl. Phys., 48, 486-492

Malik F., Khan EU, Qureshi IE, Husaini SN, Sajid M, Karim S, Jamil K (2002). Swelling in CR-39 and its effect on bulk etch rate. Radiation", Radiation Measurements 35, 301-305 .

Mansour H. L. , Karim M. S., Al-Alawy R. D. and Mishjil K. A. (2010 ):" The Determination of radon gas concentration in soil and water samples in Baghdad and Anbar governorates by using nuclear track detector (CR-39), The seventeenth scientific conference of the college of education Al-Mustansiriyah university, p632-647 .

Marovic G. and J. Sencar ( 1995 ): 226Ra and possible water contamination due to phosphate fertilizer production, J. Radioanal. Nucl.Chem., Letters.,200,9-18, 
Mowlavi A., Fornasier M.R., Binesh A., and Denasier M. (2012): "Indoor radon measurement and effective dose assessment of 150 apartments in Mashhad, Iran" Environ Monit Assess,.184, 10851088.

Pzrbylowicz W., Skowronski A., Nuclieonika (1977):Vol. 22 , P. 401

Saad B.M. (1998), Determination of Radon Concentrations in Buildings by Using Nuclear Track Detector (CR-39)" M.Sc. Thesis, College of Education, Ibn-Alhaitham ,University of Baghdad

United Nations Scientific Committee on the Effects of Atomic Radiation (UNSCEAR 2000): Report to the general assembly, with scientific annexes. Sources and effects of Ionizing Radiation,. New York, United Nation. 


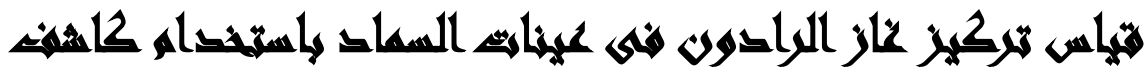

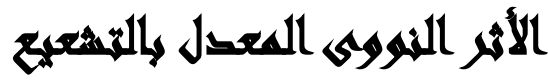

\section{$[r]$}

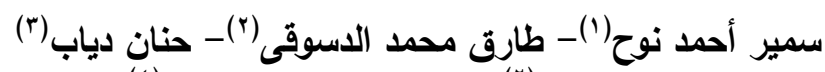

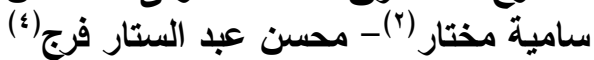

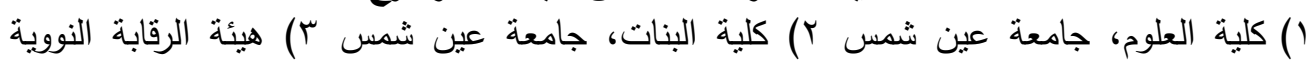

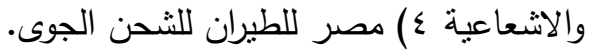

\section{vingarill}

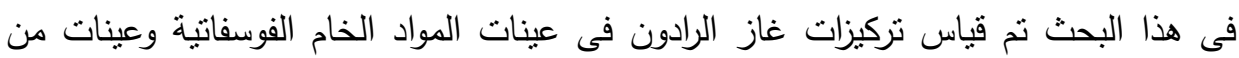

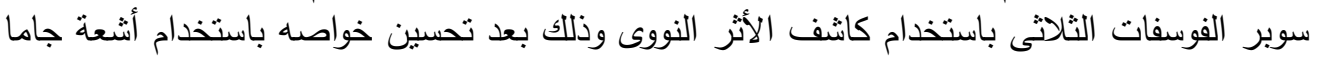
عند جرعة 20 Gy قبل تعريض هذه العينا ت لأشعة الفا.

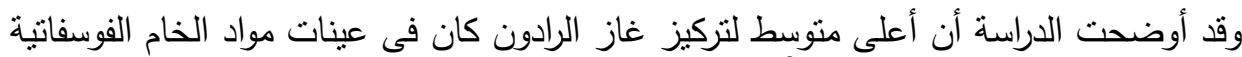
حيث كانت متوسط تركيز غاز الرادون 269.62 Bq/m³ عينات سوبر فوسفات الثلاثى

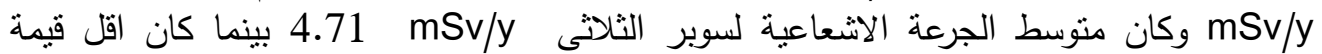
لمتوسط غاز الرادون لسوبر الفوسفات الاحادى فكانت لسوبر الفوسفات الاحادى كانت

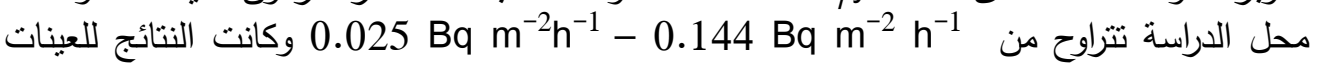
محل الدراسة فى المدى المسموح به للوكالة الدولية للوقاية من الاشعاع 